\title{
Michał Nowakowski*
}

Uniwersytet Szczeciński

\section{OCENA WIARYGODNOŚCI INFORMACJI W SERWISACH INTERNETOWYCH}

\section{Streszczenie}

Artykuł przedstawia problematykę oceny jakości i wiarygodności informacji dostępnych na stronach internetowych. W tym celu najpierw scharakteryzowano kryteria oceny jakości informacji ze względu na dokumenty elektroniczne oraz udostępniające je media elektroniczne. Następnie, zaproponowano trzy różne metody oceny kryteriów, takie jak metoda ekspertowa, metody techniczne i statystyczne. Na koniec opisano trzy praktyczne strategie wyszukiwania informacji oraz oceny ich jakości i wiarygodności pod kątem wybranych kryteriów i metod.

Słowa kluczowe: jakość informacji, wiarygodność informacji, kryteria oceny jakości informacji, metoda ekspertowa, strategie wyszukiwania informacji, infobrokering

\section{Istota jakości i wiarygodność informacji}

W obecnych czasach informacja staje się jeszcze wartościowszym zasobem. Dzięki masowej komputeryzacji i ciągłemu rozwojowi sieci teleinformatycznych zarządzanie coraz większą ilością informacji staje się łatwiejsze, niż kiedykol-

\footnotetext{
Adres e-mail: michal.nowakowski@wneiz.pl.
} 
wiek wcześniej. Niestety, wraz z jednoczesnym rozwojem społeczeństwa wiedzy, coraz większym problemem staje się również nadmierna ilość i słabnąca jakość dostępnych informacji. Globalna sieć internetowa jest narzędziem, dającym $\mathrm{z}$ jednej strony nieograniczone możliwości wymiany i pozyskiwania informacji, a z drugiej strony będącym miejscem, w którym ich nadmiar stwarza zagrożenia pojawiania się informacji niesprawdzonych lub nieprawdziwych. Wpływają na to m.in. duża wolność informacyjna oraz coraz większa komercjalizacja sieci internetowej.

Stworzenie jednoznacznej definicji pojęcia „wartość informacji” jest trudne, bowiem związane jest ono z subiektywnym postrzeganiem zdobytej informacji. Zależy ponadto od poziomu wiedzy, zainteresowań i potrzeb informacyjnych użytkownika. Jakość i wiarygodność informacji są obecnie jednymi z najbardziej poszukiwanych jej atrybutów. Dlatego głównym zadaniem wszelkich specjalistów od informacji jest dostarczanie tych sprawdzonych, wiarygodnych i relewantnych informacji.

Jedną z dziedzin zajmujących się komercyjnie zdobywaniem odpowiedniej jakości informacji jest infobrokering. Jest to określenie odnoszące się do firm świadczących usługi informacyjne polegające na wyszukiwaniu, selekcjonowaniu, analizie i dostarczaniu określonych informacji. Brokerzy informacji nie sprzedają informacji, a jedynie swoje umiejętności w zakresie ich odnalezienia. Agencje infobrokerskie przy realizacji zleceń najczęściej posługują się analizą źródeł wtórnych, takich jak bazy danych, rejestry, archiwa czy zasoby bibliotek. Rzadziej sięgają po metody pozyskiwania informacji charakterystyczne dla wywiadowni gospodarczych, jak wywiad bezpośredni czy analiza dokumentów przedsiębiorstwa (infobrokerska.pl; wiarygodnosc.cba.pl).

\section{Internetowe źródla przechowywania informacji}

Większość dostępnych w Internecie informacji znajduje się na stronach WWW. Można do nich dotrzeć $\mathrm{z}$ wykorzystaniem programu narzędziowego typu przeglądarka internetowa, która służy przede wszystkim do przeglądania zawartości stron w postaci graficznej lub tekstowej. Chcąc zapoznać się z treścią wybranej strony, należy wpisać jej adres w przeglądarce, a następnie przejrzeć dostępne na jej podstronach treści. Drugą metodą docierania do interesujących informacji jest skorzystanie z serwisów, które zbierają i katalogują ciekawe strony sieciowe, 
a następnie udostępniają ich adresy w jednym miejscu. Do serwisów tego typu należą: portale internetowe, serwisy informacyjne, encyklopedie i słowniki czy katalogi stron WWW. Innym rodzajem serwisów internetowych z wartościowymi treściami są aplikacje i usługi udostępniające dostęp do specjalistycznych baz danych na takie tematy, jak administracja samorządowa, działalność gospodarcza, bankowość elektroniczna, informacje biznesowe czy zdrowie publiczne. Dostęp do nich jest jednak możliwy tylko w sytuacji, gdy zna się ich adresy WWW.

W sytuacji, gdy nie są znane żadne adresy serwisów internetowych z poszukiwanymi informacjami można wykorzystać trzecią metodę. Jest nią użycie specjalnych serwisów typu wyszukiwarki internetowe, których zadaniem jest wyszukiwanie stron WWW o zadanej przez użytkownika tematyce. Tematykę tę można definiować za pomocą interesujących haseł w postaci słów kluczowych, które wpisuje się w polu wyszukiwarki. Poszukiwanie informacji z wykorzystaniem wyszukiwarek internetowych to $\mathrm{w}$ praktyce jedna $\mathrm{z}$ najczęściej wykonywanych operacji przez użytkowników Internetu. Warto zwrócić uwagę na to, że tą samą metodą z wykorzystaniem słów kluczowych można przeszukiwać zawartość samych serwisów internetowych, które w tym celu w większości przypadków, udostępniają system wyszukiwania informacji na swoich stronach. Znalezione w ten sposób dokumenty elektroniczne można następnie oceniać pod kątem podanych wyżej kryteriów oraz z wykorzystaniem opisanych metod (Bremer, 2011).

Jedną z najpopularniejszych i najczęściej używanych od wielu lat wyszukiwarek internetowych na świecie jest Google, która w swojej bazie ma prawdopodobnie największą liczbę zaindeksowanych stron spośród wyszukiwarek o darmowym dostępie, co sprawia, że jest ona wykorzystywana zarówno przez osoby indywidualne, firmy, jak i różne instytucje. Ponadto do jej innych zalet należą szybkość i sprawność działania, niezawodność, możliwość przeszukiwania różnego rodzaju dokumentów elektronicznych czy korzystania z rewolucyjnych usług dla użytkowników Internetu. Obok głównej usługi ogólnego przeglądania Sieci, są również dostępne wersje dedykowane materiałom naukowym, które udostępnione są jako usługi o nazwach Google Scholar i Google Books. Warto zwrócić uwagę, że wyszukiwarka Google nie jest jedyną tego typu usługą wyszukiwania informacji i oprócz niej na rynku działa wiele innych serwisów o wypracowanej przez lata renomie. Do tych serwisów można m.in. zaliczyć zagraniczne Yahoo!, Bing czy Ask oraz polskie Onet, WP czy NetSprint (Gemius Ranking; Kliszczak, 2014). 


\section{Kryteria oceny jakości i wiarygodności informacji}

Ponieważ informacja staje się obecnie coraz bardziej wartościowym zasobem, odpowiednia jej jakość jest kluczowym czynnikiem w podejmowaniu decyzji o różnym znaczeniu. Masowe rozpowszechnienie Internetu spowodowało dostęp do ogromnej ilości informacji, które z kolei są przechowywane i udostępniane w różnych postaciach. Do najczęściej wykorzystywanych form przekazu informacji drogą elektroniczną należą tekst, obraz, dźwięk, animacja oraz klip wideo. Formy te reprezentowane są następnie poprzez pliki i dokumenty elektroniczne, które z kolei umieszczane są na stronach internetowych w postaci plików dołączonych lub zagnieżdżonych. Strona internetowa w postaci dokumentu HTML jest również dokumentem elektronicznym, który w odróżnieniu od pojedynczych plików z danymi określonego rodzaju, może przechowywać jednocześnie różnorodne formy treści, począwszy od danych tekstowych, aż po treści multimedialne. Taka różnorodność dokumentów elektronicznych, dostępnych w sieci Internet, powoduje z jednej strony możliwości dostępu do ogromnej ilości informacji, ale z drugiej potrzebę ich weryfikacji pod względem jakościowym (Evaluating Web Pages).

Poddając ocenie jakość, a co za tym idzie również wiarygodność informacji w Internecie należy wziąć pod uwagę jej treść oraz formę prezentacji. Oceniając treści stron internetowych należy zwrócić uwagę na szereg kryteriów, takich jak zakres tematyczny, poprawność, kompletność, obiektywność czy aktualność danych. W ocenie formy prezentacji treści należy zaś wziąć pod uwagę technologię wytworzenia danej strony internetowej, jej popularność, dostępność, użyteczność czy też możliwość pełnego korzystania z serwisu bez dodatkowych opłat. Listę najczęściej wykorzystywanych kryteriów do oceny jakości i wiarygodności informacji w kontekście zawartości dokumentów oraz udostępniających je mediów elektronicznych opisano poniżej, w postaci dwóch różnych grup. Jako medium elektroniczne rozumiana jest pojedyncza strona lub cały serwis internetowy, które jak wcześniej opisano przechowują i udostępniają dokumenty w postaci elektronicznej (Bednarek-Michalska, 2007; Karciarz, 2010).

Do kryteriów oceny jakości i wiarygodności informacji udostępnianych w dokumentach elektronicznych można zaliczyć przede wszystkim następujące ich atrybuty (Evaluating Information Found on the Internet; Holmes, 1996; Mascott 2006): 
- aktualność (określenie czy znalezione dokumenty posiadają datę publikacji, czy treści są aktualne tematycznie, czy częstotliwość aktualizacji treści jest zgodna z jej zawartością),

- autorytet (określenie czy znalezione dokumenty są podpisane nazwiskiem autora, czy autor ten jest specjalistą/ekspertem w danej dziedzinie),

- dokładność (określenie czy treść znalezionych dokumentów jest adekwatna do poziomu wiedzy, jaki reprezentuje odbiorca, czy precyzyjnie i dokładnie określa ona temat),

- dostępność (określenie czy znalezione dokumenty są dostępne w momencie, kiedy są potrzebne właściwym odbiorcom),

- kompletność (określenie czy znalezione dokumenty zawierają odpowiednią liczbę danych, które są wystarczające, aby móc je przetworzyć w konkretną wiedzę),

- poprawność (określenie czy znalezione dokumenty zawierają treści poprawne edycyjnie, gramatycznie, ortograficznie i stylistycznie),

- relewantność (określenie czy znalezione dokumenty posiadają treści odpowiadające poszukiwanym informacjom, czy treści te odpowiadają na potrzeby i mają znaczenie dla odbiorców informacji),

- rzetelność przekazu (określenie czy znalezione dokumenty posiadają informacje potwierdzające prawdziwość przekazywanych danych, czy zawierają elementy zapewniające rzetelność przekazu).

Do kryteriów oceny jakości i wiarygodności informacji ze względu na udostępniające je media elektroniczne można zaliczyć przede wszystkim następujące ich atrybuty (Holmes, 1996; www.infobrokerska.pl; Karciarz, 2010):

- aktualność (określenie czy znalezione dokumenty znajdują się w serwisie działającym w Internecie od dłuższego czasu, czy serwis posiada informacje o dacie powstania i ostatniej aktualizacji),

- aspekty prawne (określenie czy znalezione dokumenty znajdują się w serwisie posiadającym informacje nt. polityki prywatności, procedur przetwarzania danych, polityki bezpieczeństwa danych),

- autorytet (określenie czy znalezione dokumenty znajdują się w serwisie powszechnie znanym i cieszącym się prestiżem, czy serwis może pochwalić się pozytywnymi opiniami na swój temat w Internecie),

- dostępność (określenie czy znalezione dokumenty znajdują się w serwisie dostosowanym do przeglądania z poziomu różnych przeglądarek, 
czy możliwy jest ich odczyt zarówno w wersji tekstowej i graficznej, czy serwis wolny jest od błędów oprogramowania, czy dostęp do treści serwisu jest bezpłatny, czy serwis pracuje na odpowiedniej jakości serwerze, czy serwis wspiera osoby z różnymi niepełno sprawnościami),

- kompletność (określenie czy znalezione dokumenty zawierają wystarczającą liczbę danych dla wybranego tematu, czy posiadają odesłania do innych stron, czy odesłania te działają prawidłowo i są wartościowe),

- obiektywizm (określenie czy znalezione dokumenty znajdują się w serwisie posiadającym obiektywnie napisane treści i komentarze, czy w serwisie są dostępne odnośniki do innych konkurencyjnych stron, czy zachowano równowagę między jednym punktem widzenia, a innym, czy serwis wykorzystuje tzw. treści propagandowe na swoich stronach),

- odpowiedniość formy (określenie czy znalezione dokumenty znajdują się w serwisie posiadającym określony cel swojego działania, czy wszystkie dokumenty posiadają odpowiedni opis i prezentację, czy treści tekstowe uzupełniane są zdjęciami, grafikami i innymi dokumentami lub efektami multimedialnymi, czy stosuje się najnowsze rozwiązania technologiczne do przekazywania informacji i poszerzania oferty),

- popularność (określenie czy znalezione dokumenty znajdują się w serwisie posiadającym licznik odwiedzin oraz ogólne statystyki odwiedzin, jaka jest liczba stron odwołujących się, czyli linkujących, do serwisu, czy umieszczone na stronach serwisu linki działają poprawnie),

- użyteczność (określenie czy znalezione dokumenty znajdują się w serwisie z intuicyjnym interfejsem użytkownika, czy właściwie dobrano treści pod kątem grupy docelowych użytkowników, czy serwis posiada system pomocy, czy istnieją w serwisie wersje obcojęzyczne, czy serwis posiada odpowiednią interaktywność stron, czy jest możliwość komunikacji z właścicielem/administratorem serwisu),

- wizerunek (określenie czy znalezione dokumenty znajdują się w serwisie posiadającym dobry wizerunek pod kątem grafiki, typografii i intuicyjnego podziału informacji na stronie głównej i podstronach, jakiego rodzaju domena obsługuje serwis, czy serwis posiada oryginalną szatę graficzną, itp.),

- wlasność (określenie czy: znalezione dokumenty znajdują się w serwisie dla którego można określić właściciela, formę, charakter prawny serwisu). 


\section{Metody i narzędzia oceny jakości informacji elektronicznej}

Wymienione wcześniej dwie grupy kryteriów oceny jakości informacji wyróżnia to, że mają w większości przypadków charakter jakościowy. Oznacza to, że trudno jest nadać im, niezależnie od okoliczności, identyczne wartości wynikowe, gdyż mogą one być różnie oceniane przez różnych odbiorców, w zależności od ich indywidualnych potrzeb informacyjnych. W związku z tym do oceny takich kryteriów należy użyć metod o charakterze jakościowym, dzięki którym można te kryteria oceniać $\mathrm{z}$ wykorzystaniem procedur analizy jakościowej (Adams, 2003; Bednarek-Michalska, 2007; www.infobrokerska.pl). Do metod jakościowych oceny informacji w zastosowaniach sieciowych można zaliczyć następujące metody:

- metodę ekspertową (metoda analityczna),

- metody techniczne (metody automatyczne),

- metody statystyczne (metody automatyczne).

Metoda ekspertowa to jedna z metod oceny heurystycznej, bazująca na grupowej ocenie dokonywanej przez specjalistów z wybranej dziedziny. W metodach heurystycznych wykorzystuje się opinie i oceny różnych osób (ekspertów, profesjonalistów i nieprofesjonalistów) zaangażowanych w rozwiązywanie danego problemu - znajdowanie faktów i związków między nimi oraz formułowanie własnych nieskrępowanych osądów i propozycji rozwiązań. Metody te wykorzystują osiągnięcia heurystyki, czyli dyscypliny zajmującej się badaniem procesów twórczego myślenia i formułującej zalecenia, których zastosowanie umożliwia efektywniejsze rozwiązywanie problemów. Podejście heurystyczne do problemu oznacza rozbudzenie fantazji, wyobraźni i intuicji oraz koncentracji na twórczych elementach rozwiązywanego problemu (Antoszkiewicz, 1990). Podstawowym założeniem metody heurystycznej jest korzystanie z oceny wielu ekspertów, co uzasadnia się faktem, że trafność sądów grupowych jest zazwyczaj wyższa niż indywidualnych osób. Informacje dotyczące przedmiotu badań otrzymane od grupy są co najmniej tak wartościowe, jak od każdego z uczestników grupy z osobna. Poza tym duża wiedza jednych ekspertów w określonej dziedzinie może rekompensować niewiedzę innych ekspertów, którzy posiadają szeroką wiedzę w innych dziedzinach. Odpowiedni dobór ekspertów, którzy mają ze sobą współpracować i wymieniać się swą wiedzą, często powoduje, że równoważą się ich poglądy (Cieślak, 1997). 
Oceniając jakość informacji dostępnych w serwisach internetowych można stosować tzw. metodę jakościowo-heurystyczną, zwaną także metodą ekspertową. Metoda ta polega na stosowaniu twórczych procedur podczas oceniania, co może nie gwarantować znalezienia optymalnego, a często nawet prawidłowego rozwiązania problemu. Jednak jej główna siła tkwi w możliwościach oceny zjawisk o charakterze jakościowym, które są oceniane przez ekspertów na podstawie ich doświadczenia i subiektywnych odczuć. W metodzie jakościowej stosuje się najczęściej kryteria oceny treści i formy prezentacji informacji przedstawionych na stronach serwisu, które powinny być zgodne z ogólnie przyjętymi standardami, tworzonymi przez organizację World Wide Web Consortium (Mirecka, 2003). Innym podejściem przy wyborze istotnych dla użytkowników kryteriów jest stosowanie heurystyk, czyli zgodności tych kryteriów z określonymi zasadami.

Procedura badawcza metody ekspertowej składa się z następujących etapów (Kalbach, 2008):

1. Zdefiniowanie celu i problemu badawczego.

2. Wybór ekspertów do badania.

3. Określenie listy kryteriów lub heurystyk podlegających weryfikacji.

4. Określenie sposobu oceny każdego z kryteriów, z uwzględnieniem takiego samego systemu wag dla każdego z kryteriów - za pomocą systemu ocen wartościowych (np. 1-10) lub lingwistycznych (np. „mała”, „średnia”, „duża”).

5. Przygotowanie i wysłanie kwestionariusza zawierającego pytania odnośnie każdego z kryteriów do wybranych ekspertów.

6. Analiza uzyskanych odpowiedzi.

7. Prezentacja wyników.

Powyższa procedura metody ekspertowej może być stosowana zarówno w odniesieniu do zjawisk występujących w formie tradycyjnej (np. ocena sytuacji gospodarczej przedsiębiorstwa), jak i wirtualnej (np. ocena jakości informacji w portalu). Najczęściej stosowanym narzędziem badawczym wykorzystywanym do oceny jakości za pomocą metody ekspertowej jest kwestionariusz ankietowy, którego przeprowadzenie i analiza może stanowić wsparcie w procesie podejmowania decyzji czy analizowaniu zjawisk ekonomicznych.

W praktyce metoda ekspertowa to najbardziej efektywna i miarodajna metoda z punktu widzenia użytkownika, który chce podejść krytycznie do znalezionych informacji. Metoda ta polega na wieloaspektowym przyjrzeniu się informacjom, na zrozumieniu ich cech formalnych i treściowych oraz określeniu, które 
$\mathrm{z}$ nich są najważniejsze $\mathrm{w}$ danym momencie i odpowiadają na konkretne potrzeby informacyjne. Zastosowanie metody ekspertowej do oceny jakości i wiarygodności informacji polega na użyciu pełnej lub częściowej procedury badawczej dla znalezionych w Internecie dokumentów elektronicznych. Wynikiem badania na ekspertach są jakościowe oceny opisowe i wartościowe, określające poziom spełnienia wewnętrznych wymagań i preferencji ekspertów przez poszczególne kryteria jakości informacji. Następnie uzyskane w ramach poszczególnych kryteriów oceny jakościowe, zamienia się na odpowiadające im wartości, które potem się sumuje. Tak przeprowadzona analiza ilościowa wyników, uzyskanych z metody ekspertowej, pozwala na stworzenie rankingu kryteriów oraz ocenę jakości informacji w serwisie, wyrażoną wielkościami liczbowymi. Warto tu zwrócić uwagę na fakt, iż ekspertami nie muszą być wyłącznie specjaliści z danej branży, ale również użytkownicy mający podstawową wiedzę na temat wyszukiwania informacji i przeglądania ich pod kątem pożądanej treści.

Z kolei, metody techniczne polegają głównie na wykorzystaniu gotowych narzędzi informatycznych, które analizują w sposób zautomatyzowany strony internetowe pod różnym względem i generują na tej podstawie określone wyniki. Wykorzystując te metody można m.in. zdobywać informacje o właścicielach domen, weryfikować ich kody źródłowe, sprawdzać poprawność języka HTML czy pokazywać błędy składni i stopień zgodności ze standardami sieciowymi.

Do przykładów zastosowania tego rodzaju metod można zaliczyć następujące narzędzia internetowe:

- usługa WHOIS - www.dns.pl/cgi-bin/whois.pl (aplikacja internetowa pozwalająca na sprawdzenie szczegółowych informacji na temat zarejestrowanej nazwy domeny internetowej),

- walidator HTML - www.validator.w3.org (aplikacja internetowa pozwalająca na sprawdzenie dokumentu HTML pod kątem błędów składniowych),

- walidator CSS - www.jigsaw.w3.org/css-validator (aplikacja internetowa pozwalająca na sprawdzenie arkuszy styli CSS pod kątem błędów składniowych),

- Web Page Analyzer - www.websiteoptimization.com/services/analyze (aplikacja internetowa pozwalająca na analizę wybranego serwisu internetowego pod kątem szybkości działania oraz rozmiarów i ilości zastosowanych w serwisie plików i dokumentów elektronicznych). 
Metody statystyczne polegają na wyciąganiu wniosków z automatycznej analizy liczby dostępnych danych, ilości zastosowanych odnośników, wyliczaniu ruchu użytkowników na stronach, frekwencji wyrazów kluczowych czy innych podobnych statystycznych aspektów.

Jako przykłady zastosowania tego rodzaju metod można wskazać następujące narzędzia internetowe:

- Google Analytics - pl.wikipedia.org/wiki/Google_Analytics (internetowe narzędzie do analizy statystyk serwisów WWW udostępniane przez Google; do głównych funkcjonalności tego narzędzia można m.in. zaliczyć generowanie około 80 rodzajów raportów związanych ze zbieraniem danych dotyczących ruchu internetowego, wskaźników konwersji i ROI, możliwość tworzenia segmentów użytkowników według źródła ruchu lub zachowania w serwisie, eksportowanie raportów do różnych formatów, integracja z aplikacjami e-commerce czy dostępność API),

- wskaźnik Google PageRank - pl.wikipedia.org/wiki/PageRank' www. prchecker.info (metoda nadawania, indeksowanym w wyszukiwarce Google stronom internetowym, określonej wartości liczbowej oznaczającej ich jakość; wskaźnik Google PageRank dla serwisu obliczany jest m.in. na podstawie następujących analiz popularności, ruchu w serwisie, jakości linków, częstotliwości występowania danego wyrazu),

- wskaźnik Alexa Rank - pl.wikipedia.org/wiki/Alexa_Internet; www. alexa.com/siteinfo (wskaźnik tworzony na podstawie danych zbieranych przez narzędzie Alexa ToolBar, dzięki któremu badany jest ruch, jaki generują strony internetowe; uzyskiwane informacje mówią o tym ilu użytkowników z zainstalowanym narzędziem odwiedza dany serwis oraz ile stron tego serwisu jest przez nich przeglądanych; wskaźnik Alexa Rank dla serwisu obliczany jest m.in. na podstawie następujących analiz: ruchu w serwisie, liczby wejść w ostatnich latach i miesiącach, szybkości ładowania stron, liczby linków do serwisu, recenzji),

- Wayback Machine - archive.org/Web (aplikacja internetowa stanowiąca ogromne archiwum stron internetowych i pozwalająca na przeglądanie praktycznie dowolnej strony pod kątem jej wyglądu i zawartości w przeszłości; dzięki temu narzędziu możliwy jest np. powrót do publikowanych kiedyś informacji oraz porównanie ich ze stanem obecnym). 


\section{Strategie wyszukiwania oraz oceny jakości i wiarygodności informacji}

Do wyszukiwania informacji sieciowych, a następnie oceny ich jakości i wiarygodności w celu dalszego wykorzystania i przetwarzania, można zastosować poniższe strategie wyszukiwawcze.

Pierwszą z nich jest wyszukiwanie informacji na poziomie podstawowym. Strategia ta charakteryzuje się dużą prostotą, gdyż ogranicza się najczęściej do uruchomienia popularnej wyszukiwarki internetowej i wpisania słów kluczowych, które w jakiś sposób wiążą się z pożądanym tematem. Kolejnym krokiem jest przeglądanie uzyskanych w wynikach wyszukiwania stron internetowych i weryfikacja ich pod kątem zawartości interesujących informacji. Można przy tym założyć, że chcąc uzyskać więcej informacji na dany temat lub skuteczniej odnaleźć poszukiwane treści czasami trzeba przejrzeć dużo więcej wyników wyszukiwania niż tylko kilka pierwszych stron generowanych przez system wyszukujący. Pomimo tego, w sytuacji braku poszukiwanych treści, zawsze można zmienić użyte słowa kluczowe. Choć strategia ta nie gwarantuje wysokiej jakości zdobytych informacji, to pozwala na stosunkowo szybki sposób ich zdobywania.

Kolejną ze strategii jest wyszukiwanie informacji na poziomie bardziej zaawansowanym. Strategia ta polega na rozszerzeniu podejścia podstawowego o dodatkowe działania wyszukiwawcze. Po pierwsze, należy się zastanowić jakie słowa kluczowe zastosować oraz jak szeroko definiować zapytanie, aby potencjalnie poszukiwane informacje uzyskać już na pierwszych stronach wyników wyszukiwania. Po drugie, warto rozważyć dodatkowe możliwości systemów wyszukujących i skorzystać z zaawansowanych opcji wyszukiwania celem zawężenia uzyskanych wyników i zminimalizowania ich liczby. Po trzecie znowu w przypadku braku odpowiednich treści na postawione zapytania - należy szukać informacji w innych serwisach, gdyż wyszukiwarki mają najczęściej w swoich bazach tylko takie dokumenty, na które uzyskały zgodę ich autorów. Do serwisów, które mogą zawierać treści niedostępne dla popularnych wyszukiwarek internetowych, można m.in. zaliczyć wyszukiwarki internetowe w obszarze głębokiego Internetu, katalogi stron WWW, serwisy specjalistyczne, specjalistyczne bazy danych czy inne zaawansowane usługi sieciowe. Choć strategia ta pozwala na dużo bardziej precyzyjne i efektywne znajdowanie informacji, gdyż rozszerza proces ich poszukiwania do wielu różnych obszarów Internetu, to wymaga jednak poświęcenia na to dużo większej ilości czasu. 
Ostatnią z proponowanych w niniejszym artykule strategii jest wyszukiwanie informacji na poziomie zaawansowanym, a następnie ewaluacja uzyskanych informacji pod kątem spełnienia określonych wymogów jakościowych. Strategia ta polega na rozszerzeniu podejścia bardziej zaawansowanego o dodatkowe działania związane z oceną jakościową znalezionej treści przy wykorzystaniu metody ekspertowej i ogólnodostępnych narzędzi sieciowych. Procedurę oceny jakości i wiarygodności informacji zgodną ze strategią wyszukiwania na poziomie zaawansowanym przedstawiono poniżej.

Procedura badawcza wyszukiwania informacji na poziomie zaawansowanym wraz z oceną jakości uzyskanej treści składa się z następujących etapów:

1. Zdefiniowanie celu/podmiotu wyszukiwania i interesującego obszaru (np. znalezienie wszelkich danych finansowych odnośnie firmy „X” w celu określenia jej wyceny).

2. Opis celu wyszukiwania za pomocą zbioru słów kluczowych (np. wynik finansowy X, wartość przychodów X).

3. Wybór źródeł i miejsc poszukiwania informacji:

- wybór podstawowego narzędzia wyszukiwania informacji (np. wyszukiwarka internetowa Google).

- wybór dodatkowych serwisów i narzędzi wyszukiwania informacji (np. wyszukiwarka internetowa Bing, serwis Giełdy Papierów Wartościowych, serwis do wyceny stron SpeedTest).

- wybór tradycyjnych źródeł informacji lub ich odpowiedników w wersji cyfrowej (np. „Gazeta Wyborcza”).

4. Przejrzenie uzyskanych w pkt 3 wyników i zapis wszelkich, związanych $\mathrm{z}$ celem wyszukiwania, informacji w postaci trwałej do późniejszej analizy (np. adresy stron WWW, dokumenty elektroniczne, dokumenty raportów, zrzuty ekranowe, skany artykułów).

5. Potrójna weryfikacja (min. 3 różne, potwierdzone i wartościowe źródła tej samej informacji) wszelkich istotnych znalezionych informacji (pochodzących z Internetu i materiałów tradycyjnych) o tej samej lub bardzo zbliżonej treści (np. weryfikacja czy min. 3 różne źródła podają tą samą lub zbliżoną treść informacyjną).

6. Podstawowa ocena jakości i wiarygodności, znalezionych i wstępnie potwierdzonych $\mathrm{w}$ pkt 5 , informacji $\mathrm{z}$ zastosowaniem metody ekspertowej i z uwzględnieniem określonych kryteriów oceny jakości i wiarygodności informacji udostępnianych w dokumentach elektronicznych oraz ze względu 
na udostępniające je media elektroniczne (np. ocena metodą ekspertową, które ze znalezionych informacji i w jakim stopniu spełniają postawione kryteria odnośnie jakości informacyjnej treści i medium je przekazującego).

7. Rozszerzona ocena jakości i wiarygodności informacji z zastosowaniem metod technicznych i statystycznych jako dodatkowe uwiarygodnienie mediów przekazujących odnalezione informacje (np. ocena porównawcza źródeł znalezionych informacji i wybór najlepszych, jako najbardziej wiarygodnych, pod kątem: liczby błędów technicznych lub ich braku, wartości wskaźników, ilości dostępnych informacji czy szybkości działania).

8. Analiza wszystkich uzyskanych wyników i wybór informacji najlepszych jakościowo i najbardziej wiarygodnych.

Jak widać ostatnia ze strategii charakteryzuje się najdłuższą z opisywanych procedur badawczych, co powoduje, że czas jej przeprowadzenia będzie z pewnością najdłuższy. Jednocześnie jednak pozwala ona na najbardziej precyzyjne i skuteczne znajdowanie informacji, które jednocześnie mogą spełniać szereg dodatkowych kryteriów jakościowych oraz w dużo większym stopniu zapewniać wysoką wiarygodność odnalezionych informacji.

Wyżej opisane strategie pokazują, że wyszukiwanie informacji oraz ocena ich jakości i wiarygodności to proces, którego dokładność i czas trwania zależny jest od wielu czynników. W rezultacie do oceny jakości informacji powinno się zwykle stosować najważniejsze kryteria oceny treści oraz jednocześnie kilka różnych metod oceny źródeł pochodzenia informacji. Zawsze też należy pamiętać o pewnej zdrowej dozie krytycyzmu w stosunku do informacji pochodzących jedynie ze źródeł internetowych.

\section{Podsumowanie}

W obecnych czasach korzystanie z Internetu i usług sieciowych jest standardem, do którego przyzwyczaja się coraz większa rzesza ludzi niezależnie od płci, narodowości czy miejsca zamieszkania. Jednocześnie w aktywną działalność sieciową angażuje się coraz więcej użytkowników globalnej sieci. Automatycznie tworzy to coraz więcej dostępnej dla wszystkich treści, która nie zawsze jest odpowiedniej jakości, gdyż łatwość jej wprowadzania powoduje powolny zanik mechanizmów jej weryfikacji. W związku z tym istotne jest, aby każdy użytkownik Internetu miał świadomość, iż nie wszystkie treści, które uda się 
w niej znaleźć mogą posiadać wartość informacyjną. Dlatego warto poszerzać swoją wiedzę nie tylko o nowe możliwości zdobywania informacji, ale przede wszystkim o możliwości i narzędzia ich weryfikacji pod względem jakościowym i zgodności z rzeczywistością. Tyczy się to przede wszystkim firm i instytucji, dla których wartość informacji ma coraz większe znaczenie w ich działalności, ale odnosi się to także do użytkowników korzystających z technologii sieciowych wyłącznie na potrzeby prywatne.

\section{Bibliografia}

Adams S. (2003), Information Quality, Liability, and Corrections, vol. 27, no. 5, www. infotoday.com/online/sep03/adams.shtml.

Antoszkiewicz J. (1990), Metody heurystyczne. Twórcze rozwiazywanie problemów, PWE, Warszawa.

Evaluating Web Pages: Techniques to Apply \& Questions to Ask, UC Berkeley - Teaching Library Internet Workshops, www.lib.berkeley.edu/TeachingLib/Guides/Internet/Evaluate.html.

Evaluating Information Found on the Internet, www.guides.library.jhu.edu/c.php?g=20 2581\&p=1334997.

Bednarek-Michalska B. (2007), Ocena jakości informacji elektronicznej. Pułapki sieci, EBIB, 5, www.ebib.info/2007/86/a.php?bednarek.

Bremer A. (2011), Popularne ustugi internetowe, Videograf Edukacja Sp. z o.o., Chorzów.

Cieślak M. (1997), Prognozowanie gospodarcze. Metody i zastosowania.

Gemius Ranking, Wyszukiwarki - domeny, www.ranking.pl/p1/rankings/search-enginesdomains.html (30.01.2015).

Holmes M. (1996), The multiple dimensions of information quality, „Information System Management", vol. 13, no. 2.

Kalbach J. (2008), Projektowanie nawigacji strony WWW. Optymalizacja funkcjonalności witryny, Wydawnictwo Helion/O'Reilly.

Karciarz M., Dutko M. (2010), Informacja w Internecie, Wydawnictwo Naukowe PWN, Warszawa.

Kliszczak M. (2014), Jakie sq najpopularniejsze wyszukiwarki internetowe w Polsce i na świecie?, Eactive Blog, www.eactive.pl/pozycjonowanie-stron/jakie-sa-najpopularniejsze-wyszukiwarki-internetowe-w-polsce-i-na-swiecie (30.01.2015).

Mascott L. (2006), Ensuring the quality information, „KM Review”, vol. 8, no. 6. 
Mirecka E. (2003), Wyszukiwanie, selekcjonowanie i gromadzenie informacji, cz. 1, WSiP, Warszawa.

www.infobrokerska.pl/publikacje/wywiad-gospodarczy-a-infobrokering.

www.websiteoptimization.com/services/analyze.

www.wiarygodnosc.cba.pl/wstepne.html.

\section{INFORMATION RELIABILITY EVALUATION OF INTERNET SERVICES}

\section{Summary}

The article presents the issues of information quality and reliability evaluation available on the Internet. The criterions of information quality evaluation were firstly characterized due to electronic documents and electronic media that provide them. In the next step it were proposed three different methods of criterions evaluation, such as the expert method, technical and statistical methods. At the end it were described three practical strategies for information retrieval and evaluation of their quality and reliability for the selected criterions and methods.

Translated by Michat Nowakowski

Keywords: quality of the information, reliability of the information, criterions of information quality evaluation, expert method, strategies for information retrieval, infobrokering 
